\title{
Études/Inuit/Studies
}

\section{Demographic adversities and Indigenous resilience in Western} Alaska

\section{Adversités démographiques et résilience autochtone dans l'ouest de l'Alaska}

\author{
Kenneth L. Pratt, Joan C. Stevenson et Phillip M. Everson
}

Volume 37, numéro 1, 2013

URI : https://id.erudit.org/iderudit/1025253ar

DOI : https://doi.org/10.7202/1025253ar

Aller au sommaire du numéro

Éditeur(s)

Association Inuksiutiit Katimajiit Inc.

Centre interuniversitaire d'études et de recherches autochtones (CIÉRA)

\section{ISSN}

0701-1008 (imprimé)

1708-5268 (numérique)

Découvrir la revue

Citer cet article

Pratt, K. L., Stevenson, J. C. \& Everson, P. M. (2013). Demographic adversities and Indigenous resilience in Western Alaska. Études/Inuit/Studies, 37(1), 35-56. https://doi.org/10.7202/1025253ar

\section{Résumé de l'article}

Les peuples autochtones de l'Arctique ont connu, historiquement, un grand nombre d'adversités démographiques et écologiques, dont les impacts comprennent des taux de mortalité élevés et des déplacements de population. La littérature anthropologique a eu tendance à accentuer les effets dramatiques et négatifs de ces évènements sur les groupes humains - à un degré qui implique que la fabrique de la vie sociale a été dévastée. Cette étude adopte une perspective nettement différente en décrivant au contraire la résilience des populations autochtones face à des événements culturellement traumatiques; dans le cas présent, une série de maladies épidémiques et le déclin majeur d'une ressource essentielle à la subsistance. Tirant parti de la riche collection de données qui documentent les modes d'occupation et d'exploitation du rerritoire, les auteurs explorent les réactions locales aux adversités démographiques majeures qui ont touché les populations de l'ouest de l'Alaska au cours du XIX ${ }^{\mathrm{e}}$ siècle et au début du XX ${ }^{\mathrm{e}}$ siècle. 


\title{
Demographic adversities and Indigenous resilience in Western Alaska
}

\author{
Kenneth L. Pratt*, Joan C. Stevenson**, Phillip M. Everson**
}

Résumé: Adversités démographiques et résilience autochtone dans l'ouest de l'Alaska

Les peuples autochtones de l'Arctique ont connu, historiquement, un grand nombre d'adversités démographiques et écologiques, dont les impacts comprennent des taux de mortalité élevés et des déplacements de population. La littérature anthropologique a eu tendance à accentuer les effets dramatiques et négatifs de ces évènements sur les groupes humains — à un degré qui implique que la fabrique de la vie sociale a été dévastée. Cette étude adopte une perspective nettement différente en décrivant au contraire la résilience des populations autochtones face à des événements culturellement traumatiques; dans le cas présent, une série de maladies épidémiques et le déclin majeur d'une ressource essentielle à la subsistance. Tirant parti de la riche collection de données qui documentent les modes d'occupation et d'exploitation du rerritoire, les auteurs explorent les réactions locales aux adversités démographiques majeures qui ont touché les populations de l'ouest de l'Alaska au cours du XIX $\mathrm{X}^{\mathrm{e}}$ siècle et au début du $\mathrm{XX}^{\mathrm{e}}$ siècle.

\begin{abstract}
Demographic adversities and Indigenous resilience in Western Alaska
Indigenous peoples in the Arctic have historically experienced a broad range of demographic and ecological adversities, the impacts of which sometimes included high mortalities and population dislocations. The anthropological literature has tended to emphasise the dramatic, negative impacts of such events on human groups - to an extent that implies the fabric of social life was typically devastated. This study takes a markedly different perspective by instead describing the resilience of Indigenous populations in the face of culturally traumatic events; in this case, a series of epidemic diseases and major declines in a very critical subsistence resource. Drawing on a rich collection of data documenting Indigenous land use and settlement patterns, the authors explore local responses to significant demographic adversities that befell the people of western Alaska in the 19th and early 20th centuries.
\end{abstract}

* $\quad$ ANCSA Office, Bureau of Indian Affairs, Alaska Region, 3601 C Street, Suite 1100, Anchorage, AK 99503-5947, USA. Kenneth.Pratt@bia.gov

** Department of Anthropology, Western Washington University, 516 High Street, Bellingham, WA 98225-9083, USA. Joan.Stevenson@wwu.edu, peverson@wwu.edu

ÉTUDES/INUIT/STUDIES, 2013, 37(1): 35-56 


\section{Introduction}

The Indigenous peoples of the Seward Peninsula and Norton Sound were severely impacted by epidemics of smallpox in 1838-1839, measles and influenza around 1900, the influenza pandemic of 1918, and the mid-to-late 19th-century decline of caribou (Arndt 1985; Ganley 1998; Ray 1964, 1975). The epidemics killed almost entire communities, leading to corresponding losses of local historical and cultural knowledge, whereas the caribou crash forced major economic changes. But populations recovered thanks in large part to flexible systems of economic and social organisation that permitted fine-tuning of the food quest as changes occurred.

We look at the impact of these demographic events on settlements in western Alaska (Figure 1) whose histories have been documented via implementation of Section 14(h)(1) of the 1971 Alaska Native Claims Settlement Act (ANCSA), the associated records of which constitute an overlooked resource (Pratt 2009a: 24-31). Known as the "ANCSA 14(h)(1) Collection," these data contain many new and unique details about patterns of use of specific locales in the study area. Koutsky (1981a: 82) noted that remaining households lived in fewer locations post-adversity but traditional subsistence practices continued; this continuity in local economies is evident in the ANCSA 14(h)(1) data. We describe in more detail how "abandonment" of villages and functionally related sites post-adversity was more complex than the sudden disuse implied by the term. ANCSA 14(h)(1) data show the resilience ${ }^{1}$ of Indigenous cultures in responding to demographic or ecological misfortunes, and indicate that many affected settlements remained in use despite associated devastating impacts.

\section{Demographic and biocultural context}

The ANCSA legislation united Indigenous peoples of the Bering Strait region of Alaska as the Bering Straits Native Corporation (BSNC) — one of 12 land-based Native regional corporations created by the Act. This region includes the Seward Peninsula and some of the lands around Norton Sound. The BSNC represents speakers of three different Eskimo languages (Inupiaq, Siberian Yupik, and Central Yup'ik) affiliated with 16 permanent villages. ${ }^{2}$ More subdivisions of the region's Indigenous population existed through the early historic period. Researchers have defined them as regional groups/societies (Burch and Correll 1972), independent societies or "nations" (Burch 1998: 3, 8, 2006: 5-9, 114), or by the older and more confusing term "tribes" (Ray 1975: 103-109; cf. Pratt 1984: 36-48, 2009b: 16-60).

1 Herein, "resilience" means the adaptive flexibility of the region's Indigenous peoples in repeatedly overcoming major adversities and maintaining their customary ways of life.

2 No ANCSA Section 14(h)(1) work occurred on St. Lawrence Island (the Siberian Yupik portion of the Bering Straits Native Corporation region). Thus, our study is geographically focused on the Seward Peninsula and Norton Sound areas, whose Indigenous inhabitants spoke Inupiaq or Central Yup'ik languages. 


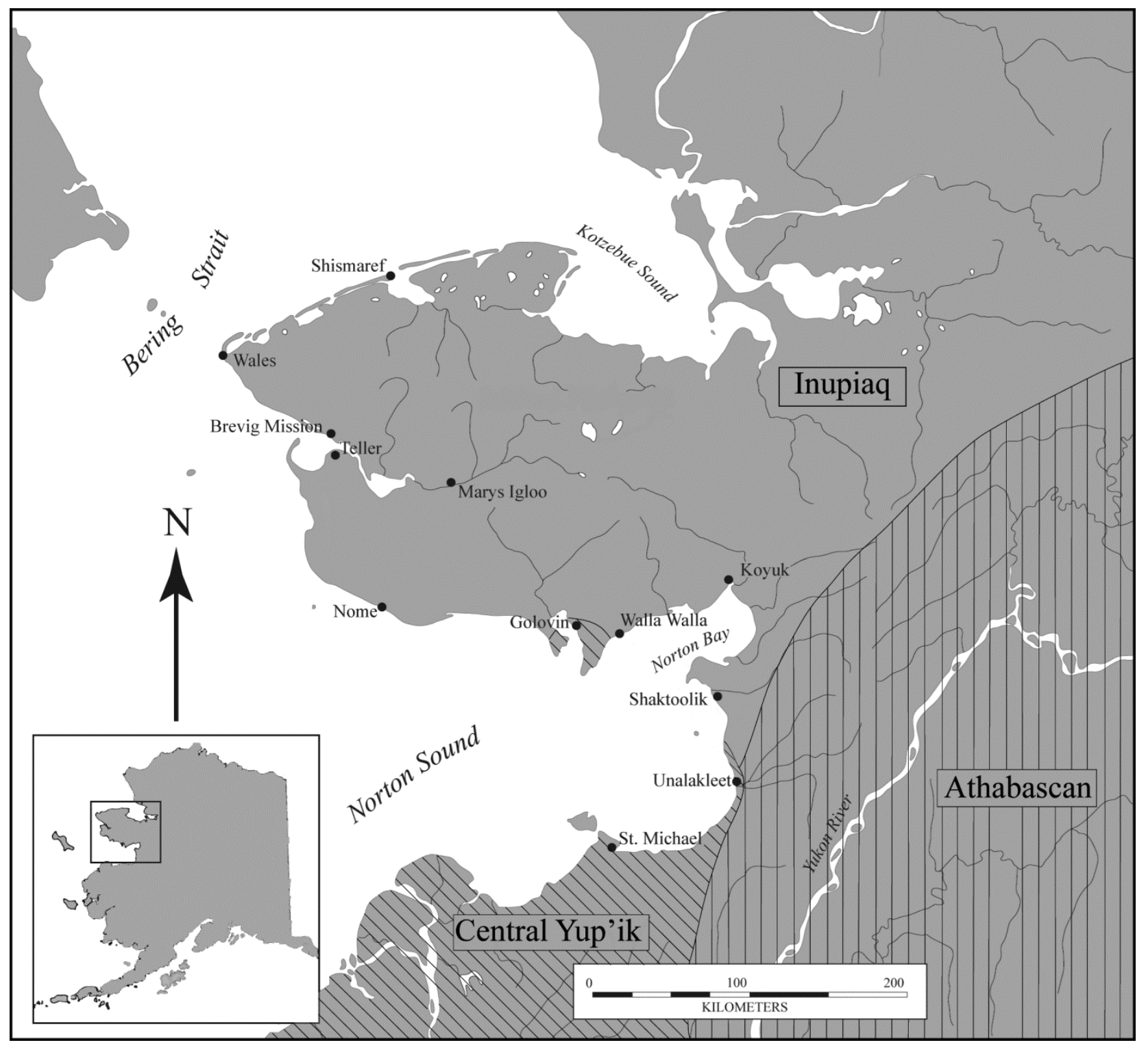

Figure 1. Study area with Indigenous language boundaries ca. 1850.

The traditional economy was based on hunting, fishing, and gathering and involved continuous adjustments in group membership and settlement for part or all of the year within the territory, depending on annual and seasonal changes in the abundance of local resources (e.g., Ray 1975: 111-120; Sheppard 1986: 305-321; cf. Burch 1998: 8-12, 2006: 102-105; Pratt 2009b: 78-87, 145-154). Settlements were typically along coastlines and river systems that allowed people to exploit a diversity of sea mammals, fish, birds, land mammals, and plant resources. Ray (1964; 1975: 104) defined three subsistence patterns for the region: whaling-walrus, caribou hunting, and small sea mammal hunting. But these patterns represented "quantitative differences in emphasis rather than absolute differences in resource use" (Stern and Ryder 2009: 1213). Groups varied in their subsistence practices generally according to location of their territories, trading relationships, and resource availability (Ray 1975: 104; $c f$. Sheppard 1983: 58-65). Kin ties, exchange networks, and occasional relocations during the annual cycle permitted everyone to access a broad range of subsistence foods, as well as vital raw materials (e.g., skins, ivory). 
The demographic events mentioned above coincided with increasing intrusions by explorers, missionaries, and miners who came from more populated regions of the world that were regularly exposed to diseases such as smallpox, measles, and influenza (e.g., Burch 1998: 324-327; Fortuine 1989; Wolfe 1982). The Native inhabitants were vulnerable to such diseases in part because of their relatively low population densities. Ray (1975: 109) reviewed population estimates by early European explorers for the 26,000 square miles between Kotzebue and Norton sounds: they range from about 2,000 to 5,000 individuals, or one person per 13 to 5.2 square miles, respectively. Such estimates are difficult to evaluate because they do not represent systematically gathered data for the entire area. They are instead rough "guesstimates" based on personal observations, sometimes supplemented with information from other sources. Season of year, richness of local resources, and age and sex structure of a particular community are among a number of factors that constantly changed and that would have influenced the size of specific settlements ( $c f$. Burch 1998: 20-21).

The anthropological literature records the local distinction between more or less populated settlements as a contrast between "villages" and "camps." Burch (2006: 102103) notes that the Inupiat of northwest Alaska made a distinction between villages occupied by some people year-round (sometimes by only one or a few families), versus camps that were visited seasonally to exploit local resources but were usually abandoned completely when those resources became unavailable. Camps were classified by season of use or resource/function. Ray also identified this contrast:

The general settlement pattern of the Bering Strait Eskimo was a large village with several small linguistically related villages located within a radius of 20 to 30 miles. Sometimes the settlements were located along a river, such as the Kuzitrin; sometimes on the ocean, as at Cape Prince of Wales. The intervening territory was considered to belong to the village cluster for hunting and fishing, an arrangement that included, ideally, the islands in reference to the mainland (Ray 1964: 61).

She further noted that:

Almost all of the villages were inhabited in the winter, and occasionally in the summer. Winter villages and summer fishing camps were located inland as well as on the coast. However, a fishing camp, unless doubling as a winter village, was not considered a permanent home. In the Bering Strait area, great importance was attached to a home village, and no matter what moves the inhabitants made during the year, one village was considered to be their "permanent" village. The term "permanent" in this paper is more or less synonymous with year-round village, and is always considered thus in a village with a kazgi $^{3}$ (Ray 1964: 61).

Thus, in Ray's conception "camp" refers to less than a year-round occupation of an area, whereas "villages" were occupied year-round. The terms had similar meanings for ANCSA 14(h)(1) researchers.

3 In currently accepted orthography, this term usually appears as qargi/qarigi (Inupiaq) or qasgiq (Yup'ik). For consistency, the Inupiaq form qargi is used hereafter. There are various definitions for these structures but one of the best is simply "community center" (Burch 1998: 12). 
The "camp" and "village" categories describe a continuum from seasonal to yearround use, respectively — by one or more households ( $c f$. Pratt 2009b: 76-87) — but they are problematic and must be interpreted in context. Semantics, the breadth of individual informants' historical knowledge, and research objectives all come into play here. If a person formerly used a site on a temporary basis without ever occupying it over the long term, it would likely be considered a camp; however, that person's contemporaries may have used the same site much differently and conceived it as a village. Descriptions of a given site as either a camp or a village also may be accurate for only a limited slice of time; reliable resource procurement sites with long histories of use may well have been occupied at different levels of intensity during different years or generations ( $c f$. ibid.: 156-190). On this point, it is worth quoting the following observation about a group that lived north of our study area: "The Kuuvaum Kayiagmiut had a taboo against living in the same house for more than one winter, so each village had to be created anew each fall even if it was inhabited by the same families who had lived there the year before" (Burch 1998: 144). Since ANCSA 14(h)(1) researchers typically did not delve into this sort of question, the identifications of camps versus villages in the associated site reports cannot be presumed to be accurate over the duration of the sites' use histories. The writings of other researchers about this region are probably similarly flawed.

Families affiliated most strongly with year-round (or "winter") villages, and such affiliation was expressed by the way local groups were designated. That is, people were collectively identified by the name of the primary village they occupied, e.g., people from Qawiaraq 4 were known as Qawiaragmiut -with the suffix "-miut" glossed as "people/residents of [a place]." Ray (1964: 62) argued that the presence of a qargi was the diagnostic indicator for whether or not a village was "permanent." This interpretation is broadly accepted among scholars of Alaska Eskimos, but it is too restrictive. For instance, such features were present at virtually all settlements on Nunivak Island, regardless of the seasonality or duration of occupation (Pratt 2009b: 157); and hunters at summer settlements in northwest Alaska were known to prop a boat on its gunwales and use it as their qargi (Burch 1998: 33).

The largest village in the study area in the early 19th century was Wales, on the western tip of the Seward Peninsula; it contained 500-600 inhabitants and four qargi (Ray 1975: 110-112). It was actually two communities ("agianamiut, on the south and kiatanamiut, on the north") with approximately equivalent populations (ibid.: 111). ${ }^{5}$ Ray classified Wales within the whaling-walrus pattern of subsistence. In contrast, villages classified in either of the other two subsistence patterns she defined generally did not exceed 50-80 people (Ray 1975: 111; cf. Burch 1980: 265).

4 Italicised place names indicate spellings that conform to Native language orthographies developed by the Alaska Native Language Center at the University of Alaska Fairbanks.

5 These "communities" were not distinct "sites" but rather factions of the Wales population associated with specific men's/community houses ( $c f$. Ray 1975: 106-107, 149-150). 
Ray's (1964: 61) term "cluster" captures the focal aspect of a winter or permanent village, as well as the residents' tendency to relocate occasionally. This flexibility compounds the confusion surrounding the terms "camp" and "village." Burch (2006: 103) thought it useful to distinguish between "simple" and "complex" settlements, i.e. those with "a single domestic or compound family" versus those with two or more compound families building their residences "in separate clusters, or neighborhoods." Consistent with the "cluster" idea is Pratt's (2009b: 86) "local group", i.e. "an assemblage of relatives who considered themselves part of one social group, lived in the same winter village, and whose boundary included all of the seasonal camps its members normally utilized."

Sites could be abandoned for many reasons (e.g., Ray 1964: 64-65). Normally, the result was not future disuse of an area. We thus use the term "abandonment" to mean the loss of any households living at a specific place all year. We are particularly interested in how demographic or ecological "shocks" influenced later settlement and subsistence patterns.

\section{The ANCSA 14(h)(1) data set}

The ANCSA included a cash settlement, granted Alaska Natives fee simple title to 40 million acres of land, and ended Aboriginal title to any other lands (Arnold 1978: 146). Part of the acreage entitlements that accrued to regional corporations such as the BSNC included Native historical places and cemetery sites, as defined in Section 14(h)(1) of the Act. More than 200 such sites were selected by the BSNC. The implementing regulations required the BSNC to identify the location of each selected site and describe its significance in Native history (see Ganley 2009). The Bureau of Indian Affairs (BIA) was assigned primary responsibility for implementing Section 14(h)(1). Associated work on the BSNC claims began in 1978 and is ongoing. Since the ANCSA regulations did not specify a methodology for investigating such claims, many inconsistencies occurred; accordingly, the development of a standard methodology was an evolutionary process (Pratt 2009a). But from the outset, site investigations included surface archaeological reconnaissance, recording of all identified cultural remains, and establishment of discrete site boundaries. Maps showing the relative locations of identifiable surface features were produced, and site histories were documented through literature reviews and oral history research with Native elders. The rich body of data resulting from these investigations is used herein, with each site identified by name (Table 1 and Figure 2) and, when first mentioned, its assigned ANCSA serial number, e.g., AA-10706, F-22894. ${ }^{6}$

6 These records constitute an archival collection that cannot be easily accessed because of inadequate processing, staffing limitations, and legal considerations. Herein, full citations to specific ANCSA records are only presented if they are being directly quoted. Other collection records consulted are keyed to their ANCSA serial numbers and represented in the references section under the cover citation "USBIA n.d." 
The program's implementation generated a complex negotiation process that at times created conflict between the parties (e.g., BSNC, BIA, National Park Service, Bureau of Land Management). The process shaped how sites were investigated and the subsequent reports configured, thus influencing site interpretations (Pratt 2009a: 7-24). For example, early reports heavily emphasised traditional subsistence practices when describing site histories, thus negatively affecting BIA decisions about the sites' eligibility for conveyance under the ANCSA regulations (which are problematic for subsistence uses of sites). Another notable point is that Section 14(h)(1) selections were accorded comparatively low priority in the ANCSA regulations, i.e., numerous other land selections allowed under the Act took precedence over these claims. The result is that many highly significant sites were categorically excluded from selection under Section 14(h)(1). Sites identified through the ANCSA process therefore do not include all known former villages and camps in the region. Nevertheless, the ANCSA data are unique because of the observations they contain about contemporary site usage (i.e., the period from about 1930 to 1985$)$.

The ANCSA data were mostly collected between 1975 and 1990 and derived in large part from oral history research with Native elders. Many of the interviewed elders formerly lived at the sites being investigated and could provide first-person accounts about site-specific topics, including seasonality and duration of use, subsistence resource harvesting activities, and site abandonment. These data were most reliable for the period after ca. 1920 but are of uneven quality due to variability in the conduct of oral history research over the life of the program (Drozda 1995: 110-115; Pratt 2004: 141-143; Sheppard 1983: 3-4).

\section{Demographic adversities}

A central goal of this study is to analyse the influences of demographic adversities on the subsequent usage and importance of affected sites. Fortuine (1989) reviewed historical references to disease and health of Alaskan Natives and documented times of likely epidemics and specific diseases. Rarely was a single disease the cause of a "catastrophe" ( $c f$. Crowell and Oozevaseuk 2006); instead, a number of factors usually created a major demographic event. Since the ANCSA 14(h)(1) Collection's ethnographic component is built on the memories of contemporary Native elders, the impacts of earlier demographic adversities are overshadowed by those of more recent ones (e.g., the 1918 influenza epidemic). Reconstructions of the earliest events discussed below are therefore heavily reliant on historical sources.

\section{Smallpox epidemic of 1838-1839}

When the Cossacks arrived in Siberia (by 1650), whatever diseases they may have introduced could easily have spread to Alaska (via trading or raids by Siberians, such as the Chukchis) prior to exploration by the Russians (e.g., Ray 1975: 10-17). Some early Russian explorers are known to have had active cases of tuberculosis, which spread 
Table 1. Sites mentioned in text (keyed to Figure 2).

\begin{tabular}{|c|l|c|l|}
\hline Map no. & \multicolumn{1}{|c|}{ Site name } & Map no. & \multicolumn{1}{|c|}{ Site name } \\
\hline 1 & Ikpik & 14 & Glacial Lake \\
\hline 2 & Izuk & 15 & Independence Reindeer Cabin \\
\hline 3 & Miłlitaavik & 16 & Eldorado River Site \\
\hline 4 & Narvaatugik & 17 & Apyinat \\
\hline 5 & Suluyaaq & 18 & Kuvravik/Ityiituq \\
\hline 6 & Piju & 19 & Tipuktuliuraq \\
\hline 7 & Agiapaum Kania & 20 & Iglutalik \\
\hline 8 & Iglu & 21 & Tuutliktuliğraq \\
\hline 9 & Qaksuqtit & 22 & Unaktuliq \\
\hline 10 & Mikuqtut & 23 & Utkusinnaq \\
\hline 11 & Ipnaq & 24 & Ungalaqliq \\
\hline 12 & Qawiaraq & 25 & Qikertaruq \\
\hline 13 & Narvaraq & 26 & Usgutarli \\
\hline
\end{tabular}

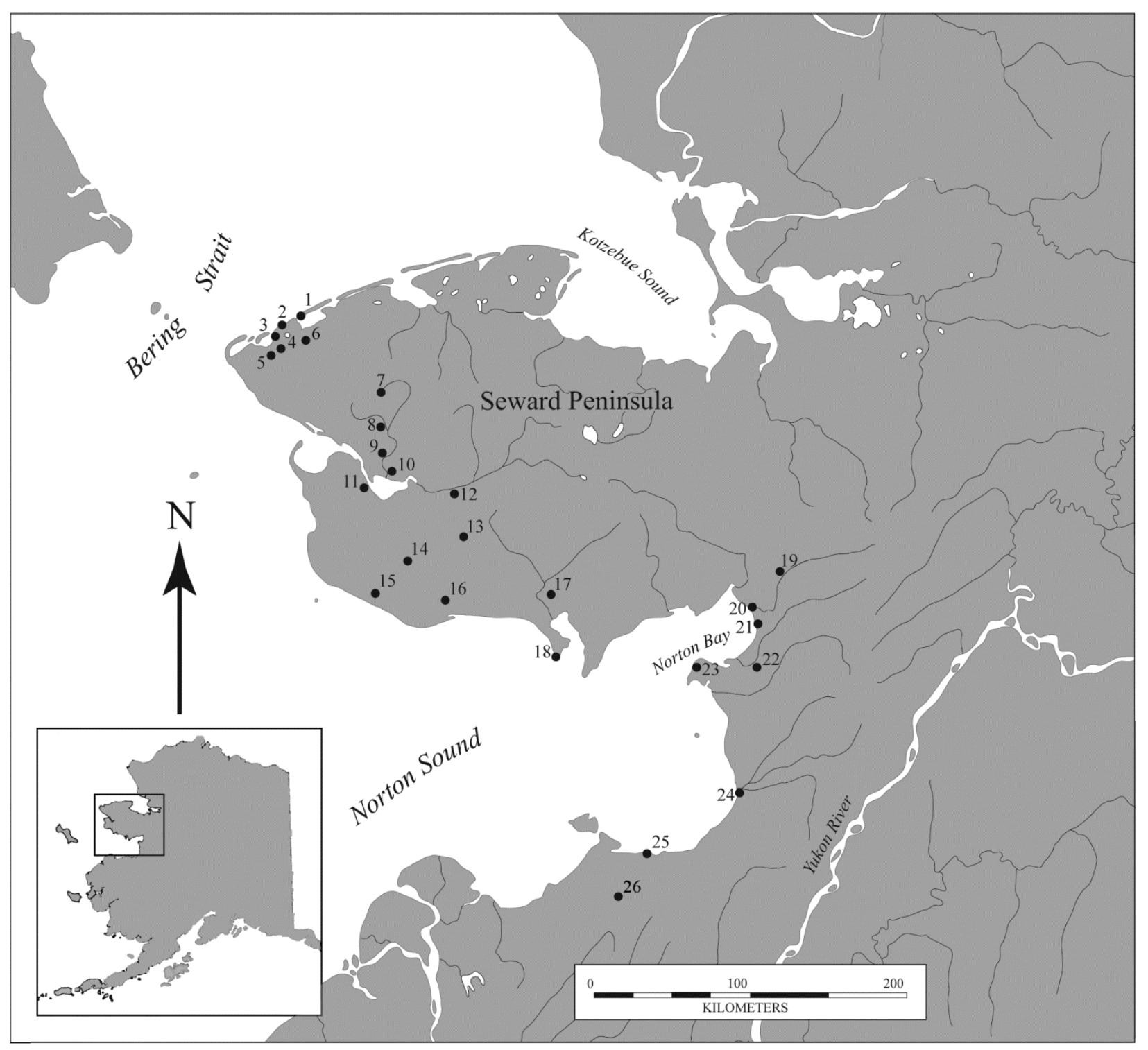

Figure 2. Location of sites mentioned in text (keyed to Table 1).

42/K.L. PRATT ET AL. 
rapidly wherever they settled (Fortuine 1989: 256-259). Because Wales was a natural stopping point for ships passing through Bering Strait (e.g., Fortuine 1989: 211), the Seward Peninsula was affected by most diseases and epidemics of the 19th century, including smallpox and respiratory diseases like influenza.

In 1833, the Russians established Mikhailovskii Redoubt (St. Michael) on what is today known as St. Michael Island, near the mouth of the Yukon River; it was the hub of Russian activity in the northern portion of Russian America. The island's two Native villages, Taciq and Atrivik (Zagoskin 1967: 100), were decimated by the smallpox that reached the Yukon Delta region in 1838 and spread up the Yukon and southern Norton Sound (Fortuine 1989: 235-236; cf. Arndt 1985). Russian Naval Lieutenant Lavrentiy Zagoskin explored the area shortly thereafter and commented on the devastation at the Yup'ik village of Ungalaqliq:

Before the smallpox epidemic there was a populous native village on the left bank of the river. Today only the hearth depressions are visible; they mark the locations of winter houses and kazhims [men's community houses]. The 13 villagers remaining crossed over to the right bank and settled in two small winter houses, a quarter of a mile from the [RussianAmerica] Company's establishment (Zagoskin 1967: 95; cf. Pratt 2012).

Other settlements along the shores of Norton Sound were similarly impacted (Zagoskin 1967: 100). There were losses of $50 \%$ or more in some areas affected by smallpox (Arndt 1985, 1996: 44-45), which reportedly "did not extend north past Koyuk" (Ray 1975: 127, 178; cf. Koutsky 1981b: 59).

More visits by explorers and ships led to additional epidemics, some of which seemed like influenza and were often accompanied by severe respiratory complications (Fortuine 1989: 200-208). Smoky homes likely contributed to the reportedly ubiquitous eye infections (Fortuine 1989: 73-75) and may also have caused lung problems; both conditions might predispose some individuals to develop colds or seasonal influenzas that could progress to lethal bacterial infections. Infections could have spread rapidly in crowded winter homes. These illnesses were probably endemic in the late 1800s and lethal in times of food shortage, since malnutrition is immunosuppressive (Gaertner 2007; Houston et al. 2007).

\section{Disappearance of caribou}

Also occurring with the spread of endemic diseases was a virtual disappearance of caribou herds (Burch 1998, 2012; Ray 1975; cf. Pratt 2001: 37-41). The Seward Peninsula contained hundreds to thousands of caribou in the mid-1800s, but by 1900 few remained. Dall (1870: 147) argued that the use of firearms played a major role in their disappearance ( $c f$. Burch 1998: 294, 2012: 81, 113, 120; Ray 1975: 174). Large herds were apparently present near Unalakleet and Saint Michael in the mid-19th century, about which time Ray (1975: 174) suggests there may have been "a natural 
shift of the herds to the south." Either way, caribou herds in the study area were severely depleted by 1880 (e.g., Burch 1998: 270, 283, 293-294; Pratt 2001: 37).

The caribou decline likely had multiple causes, with subtle and complex interactions. It is difficult to reconstruct the chain of circumstances that led to the animals' disappearance from the Seward Peninsula ( $c f$. Burch 2012: 70-74), but observations of contemporary caribou populations provide some insights (Ferguson and Elkie 2004; Person et al. 2007). Caribou can migrate seasonally over hundreds of kilometres, and tend to return to their spring-to-summer calving locales more consistently than to their winter territories. The Seward Peninsula is a wintering site for present-day caribou - and more easily abandoned when adverse conditions prevail. Variables that can affect the persistence of local caribou subpopulations include availability of forage (particularly arboreal lichens), relative wetness of the climate, distribution of alpine areas and forests older than 140 years, harassment by mosquitoes and oestrid flies, and extent of human interference in the local ecology (e.g., Apps and McLellan 2006; Courtois et al. 2007; Post et al. 2003). Predation can override or exacerbate the effects of the other factors. Any one or all of the above factors may have made the Seward Peninsula inhospitable for wintering, and especially for calving. In any event, the loss of caribou to the people most dependent on them necessitated a shift in the pattern of resources they utilised and traded; it was also a key reason why some Seward Peninsula peoples began to migrate south in the 1860s (e.g., Ganley 1995; $c f$. Pratt 2001: 37-39, 2012).

\section{The "Great Sickness" of 1900}

Many diseases are thought to have been endemic to the Seward Peninsula by the late $1800 \mathrm{~s}$, but a series of epidemics arrived in 1900 and spread rapidly one after another (Fortuine 1989: 215-226; Wolfe 1982: 91). Wolfe examined first-hand reports by local observers (physicians, missionaries, teachers, government employees) and focused on Indigenous peoples living in the coastal regions and lower riverine areas of the western Alaska mainland. Measles and influenza were the illnesses that likely initiated the chain of events leading to high mortality (Wolfe 1982: 95). Further exacerbating the issue were sociocultural factors, population-host dynamics, and local ecologies. Wolfe (ibid.: 96) speculated that measles and influenza arrived with people looking for gold; however, local observers assumed the measles came from Asia. All observers reported massive casualties in Indigenous communities-some of which Wolfe (ibid.: 102) posits had not previously encountered these diseases. Families often could not leave their homes and nursing care and food preparation were minimal; ill people would sometimes be lying next to the dead (ibid.: 110). Concurrent illnesses, emotional and physical stress, and poor nutrition further exacerbated the vulnerability of some individuals.

The occurrence of widespread "colds" among Bering Strait Natives people coincided with the break-up of sea ice in the spring and freeze-up in the fall, the seasons during which contacts with outsiders were most extensive (ibid.: 91). 
Influenza attacks the natives soon after the snow disappears and again just before the cold and frost of winter [...] it is throughout the whole coast of Alaska from Attu to the Mackenzie River. Like the "grip" unless complications arise it runs a short and mild course. At Cape Prince of Wales, however, I understand from Mr. Lopp that the attacks were quite fatal, 19 men having died this spring (Call 1899: 123).

The likely viral infections often evolved into more serious conditions (e.g., Ray 1966: 20). Few cultural strategies were in place to cope with these diseases; shamans were often held responsible, and such accusations sometimes led to their murder or suicide (Fortuine 1989: 218; Wolfe 1982: 114). With many adults sick for long periods during the epidemic, customary subsistence activities were seriously reduced, and the threat of starvation increased. As people recovered, groups responded by moving to new locales and shifting to secondary resources for their nutrition (Wolfe 1982: 114115). Because the Eskimos' flexible socioeconomic system provided them with support to adapt rapidly, starvation usually did not occur.

\section{Influenza epidemic of 1918}

Few families worldwide were unaffected by the 1918 influenza epidemic, and many survivors recalled relatives who died and the circumstances of their deaths. This was also true of descendants of people then living on the Seward Peninsula (e.g., Oquilluk 1973: 205-208), enabling Ganley (1998: 247-248) to use interviews and census data to reconstruct the spread of the influenza virus. This catastrophe started at Nome when the ship Victoria arrived with the peninsula's mail; its subsequent arrival at St. Michael infected that community as well. The influenza did not spread from village to village between St. Michael and the Seward Peninsula, however, thanks to quarantines at Shishmaref, Walla Walla, and Unalakleet. Thus, on the Seward Peninsula the epidemic raged between Shishmaref on the north and Walla Walla on the south. The quarantine was penetrated in some locations, but the virus' spread largely followed the delivery of mail.

Ganley (1998: 249, Table 1) reconstructed the numbers of deceased per community and concluded that most communities lost at least half their population. In many locations, families were spread out in small but socially interconnected camps in coastal areas and along rivers. Predictably, the epidemic spread north and south along the coast from Nome and inland to the Imuruk Basin via Grantley Harbor and Tuksuk Channel. Mikuqtut (F-21978) and other small camps were stricken along the American and Agiapuk rivers.

The largest interior village on the Seward Peninsula during the epidemic was Marys Igloo or "Aukvaunlook" (Oquilluk 1973: 10, 216). Three reindeer herds wintered in the vicinity. There was a small herder's camp (Qaksuqtit; F-21949) on the American River, and about 10 families lived on nearby Agiapuk River. Individuals were first identified with influenza on November 15th and 23rd; a month later, 68 people were dead (Nome Daily Nugget 1918; Renner 1979: 45-49). Influenza spread rapidly to neighbouring communities east of Marys Igloo (e.g., Renner 1979: 43). 
The Native community in Nome suffered mortalities estimated at $87.5 \%$ (Ganley 1998: 249, Table 1). Remarkably, other communities were hit even harder. In Brevig Mission, 72 people in the community of 80 died between November 15 and 20, 1918. The community did not have enough able-bodied people to bury their dead. The frozen flu victims remained in the homes where they died until January 1919 (Stern and Ryder 2009: 22). According to Ganley (1998: 250), "the virus was dispatched to Wales via the mail carrier, who was traveling with a Wales resident." Within two months of its appearance in Wales, the influenza killed about 200 people, or half the population (Bogojavlensky 1969: 30). It also ravaged numerous smaller, affiliated settlements on the shores of the Seward Peninsula (Koutsky 1981b: 59). Adolescent and preadolescent children had the highest survival rates. Fifty children were orphaned by the Wales area epidemic; more may have survived had there been adults to keep fires going and prepare food (Ganley 1998: 250-251; Oquilluk 1973: 224-225). The northernmost settlement affected was Millitaavik (F-22006). Coastal settlements on the peninsula southward to Golovin were similarly affected; but quarantining spared some communities (Ganley 1998: 248, Figure 1). Trails leading to Shishmaref, an established quarantine point, were guarded by armed individuals (Ganley 1998: 250; cf. Oquilluk 1973: 225). As coastal areas recovered, however, interior settlements became particularly vulnerable.

Each of the demographic adversities just discussed was devastating to the Indigenous population and altered pre-existing settlement patterns to some degree. We will now assess how these factors influenced the subsequent choice and use of villages and related sites on the Seward Peninsula and Norton Sound.

\section{Changes in settlement and land use patterns}

Constraints involved with oral history research under the ANCSA 14(h)(1) program meant there was no consistent protocol for inventorying the resources formerly harvested at investigated sites. Some informants nevertheless described why certain areas formed the focus of a cluster of sites, and suggested that the establishment of winter villages was primarily based on rich quantities of a particularly valuable resource or a variety of available resources. ${ }^{7}$ This pattern of rich resources seems clear from data contained in ANCSA site reports. One example concerns the site of Pigu (F21963), on the Pinguk River southeast of Shishmaref.

The tundra plain and the Pinguk River offer a wide variety of seasonal resources. Many species of migratory waterfowl and marine birds nest around the small ponds and streams. The river provides whitefish and grayling. The tundra provides ample cranberries, blueberries, salmonberries, and various edible leaves and roots. Ground squirrels appear to be numerous as evidenced by the many burrows at the site. Fox and

7 Subsistence considerations notwithstanding, Sheppard (1983: 63-65) observed that the most important variable shared by winter villages in eastern Norton Sound was that all of them were located along major travel routes that facilitated the aggregation of social group members. 
brown bear have also been observed in the region. Caribou once frequented the area, but now reindeer use the grazing land (USBIA 1996: 5).

The Kuvravik (F-21936)/Ikniituq (F-21938) site area on Rocky Point south of Golovin offers another example.

The waters, shoreline and tundra surrounding Rocky Point are rich in many vital resources. Residents of several communities mentioned Rocky Point as an important sealing, fishing and crabbing locality [...]. The numerous cliff nesting birds found along the nearby rocky bluffs provide meat and eggs for human consumption. The terrestrial habitat is suitable for many animals important to the Eskimo economy and notable among them are ground squirrel, Arctic hare, snowshoe hare, grizzly bear and, formerly, caribou. The varied topography of the Rocky Point region also provides habitats for many economically important plant species (USBIA 1992: 6).

Diversity and quantity of resources during most or all of the year were high priorities but other factors are evident in remarks about Ikpik (F-21966), southwest of Shishmaref.

David Adams, a 66-year-old Brevig Mission resident, lived at Feature 47 [...] until he was 18. He reports the site is a good place — much better than Shishmaref — because it has plenty of high ground for building sites, [has] readily available drinking water and has an abundance of seals and other game (USBIA 1990: 6).

The rich resources near many settlements contributed to their continued use even after the worst disasters; so did considerations that might be called "family traditions" (cf. Pratt 2009b: 188-203; Sheppard 1986: 239-304). Epidemics did cause the demise of certain villages, ${ }^{8}$ some of which were later considered haunted and/or dangerous places to be avoided. The Yup'ik village of Ungalaqliq is especially interesting in this regard. Abandoned as a winter village following the 1838-1839 smallpox epidemic, the site was being used for summer fishing by at least 1842 (Zagoskin 1967: 95-96, 287, note 23 ), and it has evidently remained in use for the same purpose ever since. Nevertheless, local people have long considered the site dangerous because of its connection to smallpox - a belief that persists to the present day and has repeatedly frustrated efforts to conduct archaeological work there (e.g., Correll 1974: 47, note 9; Matt Ganley, pers. comm. June 2012).

These demographic events cumulatively led to changes in settlement patterns, but they did not necessarily follow consistent trajectories. Basically, there were fewer people competing for resources (now relatively more abundant) which did not include caribou. Thus, by the mid-to-late 19th century dramatic declines in use occurred at all sites closely linked with hunting or processing of caribou, e.g., Qaksuqtit, Narvaraq (F21997; Salmon Lake), and Narvaatugvik (F-21984). Some sites even appear to have been permanently abandoned as a direct result of the caribou crash, e.g., Ayniynat (F-

8 Examples from the 1918 epidemic include Mikuqtut and Qikertaruq (Sheppard 1983: 53). Iglutalik (F22849) may have suffered the same fate during the 1900 epidemic (USBIA 1989: 9). 

Agiapaum Kayia (F-22010), and Usgutarli (AA-10706).

Dispersed settlements along the shorelines of rivers and the sea continued nonetheless to be occupied, this having been always the pattern when resources were relatively abundant. Thus, Koutsky (1981a: 78) describes Iglu (F-21954) as an important winter village when Qawiaragmiut families were scattered in small settlements along the Kuzitrin and Agiapuk rivers and their tributaries. Similar descriptions of this pattern are found in numerous site reports, including the following two.

According to Koyuk elders, Utkusinnaq (F-21915) was the spring residence for several Norton Bay families and the winter residence of at least one family. Before 1928, there was no single village in Norton Bay. The winter residences of families were dispersed throughout the bay and often changed from year to year (USBIA 1988: 8).

The next report concerns the Eldorado River Site (F-21946), located midway between Nome and Solomon.

The interpretation Koutsky [1981c: 27] attached to this site as being a seasonal settlement related to fishing and duck hunting seems reasonable given the current use of the lower Eldorado River and adjacent drainages. The small rivers flowing into Safety Sound are dotted with numerous semi-permanent fishing camps. Although the numbers of these camps are exaggerated by the high population of nearby Nome, this high density is not entirely a recent phenomenon. Many of the modern fish camps were observed to have older sites associated with them; during an aerial survey of the area, other small sites were located that did not have modern camps associated with them (USBIA 1986: 7).

In fact, the data reviewed for this study revealed that many of the subject sites contain known subsurface cultural deposits indicative of prehistoric occupations-a testimony to resource reliability and enduring land use practices. It is thus no surprise that productive sites with reliable resources in proximity remained attractive to Indigenous people even after the worst of disasters had struck. The most severely affected sites were neither forgotten nor remembered solely because of such events, i.e. although epidemics often led to high human mortalities, they did not negatively impact any area's subsistence resources. Pendulum or cyclical type patterns of use were the norm for many historically occupied sites; similar patterns likely characterised prehistoric land use as well. By extension, it is reasonable to speculate that prehistoric residents of this region were also resilient in the face of ecological and other adversities.

Finally, one demographic event discussed above - the disappearance of caribouwas critical to the decision in the 1890 s to introduce reindeer herding to the Bering Strait region. Reindeer herding is not a focus of this study, but it is worth noting that Indigenous people adjusted to this foreign and often disruptive economic enterprise with resilience similar to their response to unexpected demographic adversities, as Koutsky observed: 
Reindeer herding brought new patterns of land use and lifestyle to the Eskimos. Land used for hunting was also used as grazing ground for reindeer. Herding never completely replaced the hunting and gathering economy, and the cyclic subsistence activities were integrated with the herding activities whenever possible. However, traditional cultural values were transmitted to children through the family; and herding required the herders to live away from their homes and families most of the year to follow the migrating herds, prohibiting their participation in traditional activities (Koutsky 1982: 67).

Oral accounts indicate that some "caribou-function" sites were incorporated into the reindeer economy: "After the caribou declined, [Qaksuqtit] became a winter [reindeer] herder's camp, with herders hunting fox and squirrels from which parkas were made in their spare time" (USBIA 1984: 46). Sites originally oriented toward sea mammal hunting (e.g., Izuk [F-21964]), beluga whaling (e.g., Tuutliktuligraq [F21883]) and fishing (e.g., Iglu, Tipuktuliuraq [F-21929], Independence Reindeer Cabin [F-22857], Ipnaq [F-21980]) were also incorporated into the herding economy. Even at sites established in response to the introduction of reindeer:

[...] herding never replaced traditional subsistence and economic pursuits. After the Nulloraks returned to [Uyaktuliq (F-21885)] in 1934, the patterns of use returned to more traditional modes. Mary and Norman [Nullorak] reverted to the traditional life style and harvested the abundant berries, salmon, trout, big game and fur bearers that inhabit the area. The use of [Uyaktuliq] originally as a reindeer grazing reservation and later as the center of subsistence activities illustrates the continuity of traditional life styles in the Norton Sound area (Ream 1983: 5).

\section{Conclusion}

Site abandonment in the study area was rarely permanent no matter how devastating the demographic event. Many affected sites remained in use until about the mid-20th century; some were still being used in the 1980s (e.g., Izuk, Ipnaq). This does not mean that dwellings in which epidemic victims had died were later reoccupied or that re-use of the sites followed pre-disaster patterns; nor is it our intent to downplay the tremendous loss of people and knowledge that resulted from these dramatic demographic shocks. ${ }^{9}$ But there is compelling evidence that Inupiat and Yup'ik survivors maintained their prior subsistence lifestyles and, presumably, many of their associated cultural traditions.

Its limitations notwithstanding, the ANCSA 14(h)(1) Collection demonstrates the flexibility of Indigenous economic systems by documenting the continued use of numerous villages and associated campsites post-disaster. This is possible because program research emphasised gathering of detailed information about the long-term history of use of each investigated site.

9 One reviewer of this article observed that the history of this region was presented as a series of disasters by Inupiat author William Oquilluk (1973). 
Many Seward Peninsula and Norton Sound communities were described as having been abandoned immediately after certain disasters, some of which (e.g., the caribou crash) clearly altered the economic value of given sites. But a comparatively large number of the abandoned sites were later reoccupied (e.g., Table 2). Family and individual ties to the land were obvious factors in this process. In reality, sites in productive subsistence locales were rarely abandoned unless the associated resources became seriously depleted, or the people who called those areas home either died out or migrated to new territories. The following statement by Sheppard (1986) about the Norton Bay area is also applicable to the region as a whole.

There are very good reasons to believe that the subsistence demands of Norton Bay people were nowhere near the capacity of their environment however one defines this limit. The strongest evidence for this comes from the fact that Norton Bay was progressively decimated by disease, most significantly by the 1900 measles epidemic and by the 1918 influenza epidemic. Lest we think that disease merely kept population at acceptable levels, it is evident that people were able to generate a surplus, witnessed by the fact that people could sell dry fish and devote time to specialized non-subsistence activities (Sheppard 1986: 300-301, emphasis in original).

Ultimately, the chief cause for site abandonment was the forced centralisation of populations-which occurred between ca. 1900 and 1930 primarily in response to the arrival of missionaries and the introduction of the Western educational system.

Table 2. Examples of post-demographic adversity site histories.

\begin{tabular}{|l|c|l|l|l|}
\hline $\begin{array}{c}\text { Site name } \\
\text { (Serial number) }\end{array}$ & $\begin{array}{c}\text { Prehistoric } \\
\text { component? }\end{array}$ & Original use(s) & \multicolumn{1}{c|}{$\begin{array}{c}\text { Cause of } \\
\text { abandonment }\end{array}$} & Later use(s) \\
\hline $\begin{array}{l}\text { Ungalaqliq } \\
\text { (N/A) }\end{array}$ & yes & fall/winter village & $\begin{array}{l}1838-1839 \\
\text { smallpox }\end{array}$ & summer fishing \\
\hline $\begin{array}{l}\text { Iglutalik } \\
\text { (F-22849) }\end{array}$ & yes & winter village & $\begin{array}{l}\text { "great sickness" of } \\
1900 ?\end{array}$ & summer fishing \\
\hline $\begin{array}{l}\text { Miłlitaavik } \\
\text { (F-22006) }\end{array}$ & yes & fall/winter village & 1918 influenza & $\begin{array}{l}\text { winter fishing, fox } \\
\text { trapping; spring } \\
\text { hunting }\end{array}$ \\
\hline $\begin{array}{l}\text { Narvaraq } \\
\text { F-21997) }\end{array}$ & yes & $\begin{array}{l}\text { summer/fall village; } \\
\text { caribou drive site }\end{array}$ & $\begin{array}{l}\text { caribou crash } \\
\text { ca. } 1870\end{array}$ & summer fishing \\
\hline $\begin{array}{l}\text { Iglu } \\
\text { F-21954) }\end{array}$ & unknown & winter village & 1918 influenza & $\begin{array}{l}\text { reindeer herding, } \\
\text { fox hunting }\end{array}$ \\
\hline $\begin{array}{l}\text { Mikuqtut } \\
\text { (F-21978) }\end{array}$ & unknown & winter village & 1918 influenza & none \\
\hline $\begin{array}{l}\text { Qikertaruq } \\
\text { (N/A) }\end{array}$ & unknown & winter village & 1918 influenza & $\begin{array}{l}\text { fall hunting and } \\
\text { fishing }\end{array}$ \\
\hline $\begin{array}{l}\text { Kuvravik/Ikniituq } \\
\text { (F-21936/21938) }\end{array}$ & yes & fall/winter village & 1918 influenza & $\begin{array}{l}\text { winter seal } \\
\text { hunting }\end{array}$ \\
\hline $\begin{array}{l}\text { Agiapaum Kajia } \\
\text { (F-22010) }\end{array}$ & yes & $\begin{array}{l}\text { spring/summer } \\
\text { village; caribou drive } \\
\text { site }\end{array}$ & $\begin{array}{l}\text { caribou crash } \\
\text { ca. } 1870\end{array}$ & none \\
\hline $\begin{array}{l}\text { Sulunaaq } \\
\text { F-21983) }\end{array}$ & unknown & $\begin{array}{l}\text { summer/fall } \\
\text { village }\end{array}$ & $\begin{array}{l}\text { caribou crash } \\
\text { ca. } 1870\end{array}$ & none \\
\hline
\end{tabular}


Sites whose residents were seriously affected by demographic adversities nonetheless remained in use due to their value for customary subsistence needs and practices. After the village centralisation process, such sites afforded access to subsistence resources that supplemented purchased foods, thereby ensuring food security. Subsistence foods still provide a significant amount of the total diet of Alaska Native peoples living in the study area today, but the intensity of harvesting efforts has declined and associated patterns of land use changed. These changes correlate with an increasing loss of local knowledge about former villages and camps throughout the Seward Peninsula and Norton Sound (cf. Oquilluk 1973: 225), thereby magnifying the ANCSA 14(h)(1) Collection's importance as a data source on the region's Indigenous history.

\section{Acknowledgments}

The authors thank Murielle Nagy and Peter Frost for their editorial support, Claire Alix for the French translation of our abstract, and two anonymous reviewers for comments and suggestions that helped improve this paper.

\section{Archival sources}

REAM, Bruce A.

1983 National Register of Historic Places Inventory - Nomination Form for Onnuktolik, F-21885 (Bering Straits Native Corporation), Anchorage, BIA ANCSA Office.

\section{USBIA (UNITED STATES BUREAU OF INDIAN AFFAIRS)}

n.d. Bering Straits Native Corporation: ANCSA 14(h)(1) Administrative Case Files, Anchorage, BIA ANCSA Office.

1984 Report of Investigation of Kok-suk-tik, F-21949 (Bering Straits Native Corporation), Anchorage, BIA ANCSA Office.

1986 Report of Investigation for Site 222, F-21946 (Bering Straits Native Corporation), compiled by William L. Sheppard, Anchorage, BIA ANCSA Office.

1988 Report of Investigation for Utkusinnaq, F-21915 (Bering Straits Native Corporation), compiled by William L. Sheppard, Anchorage, BIA ANCSA Office.

1989 Report of Investigation for Inglutalik, F-22849 (Bering Straits Native Corporation), written by Matthew O'Leary, Anchorage, BIA ANCSA Office. 
1990 Report of Investigation for Ikpek, F-21966 (Bering Straits Native Corporation), written by Matthew O'Leary. Anchorage, BIA ANCSA Office.

1992 Report of Investigation for Kuvrawik/Ikngiituq, F-21936 and F-21938 (Bering Straits Native Corporation), written by Terence Fifield, Anchorage, BIA ANCSA Office.

1996 Report of Investigation for Pingu, F-21963 (Bering Straits Native Corporation), written by Carol Brandt, Anchorage, BIA ANCSA Office.

\section{References}

APPS, Clayton D. and Bruce N. McLELLAN

2006 Factors Influencing the Dispersion and Fragmentation of Endangered Mountain Caribou Populations, Biological Conservation, 130(1): 84-97.

ARNDT, Katherine L.

1985 The Russian-American Company and the Smallpox Epidemic of 1836 to 1840, paper presented at the 12th Annual Meeting of the Alaska Anthropological Association, Anchorage, March 2, Copy on file, Anchorage, BIA ANCSA Office.

1996 Dynamics of the Fur Trade on the Middle Yukon River, 1839 to 1868, Ph.D. dissertation, University of Alaska Fairbanks.

\section{BOGOJAVLENSKY, Sergei}

1969 Imaangmiut Eskimo Careers: Skinboats in Bering Strait, Ph.D. dissertation, Harvard University, Cambridge.

BURCH, Ernest S., Jr.

1980 Traditional Eskimo Societies in Northwest Alaska, Senri Ethnological Studies, 4: 253-304.

1998 The Iñupiaq Eskimo Nations of Northwest Alaska, Fairbanks, University of Alaska Press.

2006 Social Life in Northwest Alaska: The Structure of Iñupiaq Eskimo Nations, Fairbanks, University of Alaska Press.

2012 Caribou Herds of Northwest Alaska, 1850-2000, Igor Krupnik and Jim Dau (eds), Fairbanks, University of Alaska Press. 
BURCH, Ernest S., Jr. and Thomas C. CORRELL

1972 Alliance and Conflict: Inter-Regional Relations in North Alaska, in Lee Guemple (ed.), Alliance in Eskimo Society, Seattle and London, University of Washington Press, Proceedings of the American Ethnological Society, 1971 (Supplement): 17-39.

CALL, Samuel J.

1899 Report of the Surgeon S.J. Call, R.C.S., in U.S. Treasury Department, Report of the Cruise of the U.S. Revenue Cutter "Bear" and the Overland Expedition for the Relief of the Whalers in the Arctic Ocean from November 27, 1897, to September 13, 1898, Washington, Government Printing Office: 114-127.

CORRELL, Thomas C.

1974 Ungalaqlingmiut: A Study in Language and Society, Ph.D. dissertation, University of Minnesota, Minneapolis.

COURTOIS, Réhaume, Jean-Pierre OUELLET, Laurier BRETON, André GINGRAS and Claude DUSSAULT

2007 Effects of Forest Disturbance on Density, Space Use, and Mortality of Woodland Caribou, Ecoscience, 14(4): 491-498.

CROWELL, Aron and Estelle OOZEVASEUK

2006 The St. Lawrence Island Famine and Epidemic, 1878-80: A Yupik Narrative in Cultural and Historical Context, Arctic Anthropology, 43(1): 1-19.

DALL, William $\mathrm{H}$.

$1870 \quad$ Alaska and Its Resources, Boston, Lee and Shepard.

DROZDA, Robert M.

1995 They Talked of the Land with Respect: Interethnic Communication in the Documentation of Historical Places and Cemetery Sites, in Phyllis Morrow and William Schneider (eds), When Our Words Return: Writing, Hearing, and Remembering Oral Traditions of Alaska and the Yukon, Logan, Utah State University Press: 98-122.

FERGUSON Steven H. and Philip C. ELKIE

2004 Seasonal Movement Patterns of Woodland Caribou (Rangifer tarandus caribou), Journal of Zoology, 262(2): 125-134.

\section{FORTUINE, Robert}

1989 Chills and Fever: Health and Disease in the Early History of Alaska, Fairbanks, University of Alaska Press. 
GAERTNER, Christine

2007 The Importance of Nutrition in Immunity, Agro Food Industry Hi-Tech, 18(2): 30-32.

GANLEY, Matt L.

1995 The Malemiut of Northwest Alaska: A study in ethnonymy, Études/Inuit/Studies, 19(1):103-118.

1998 The Dispersal of the 1918 Influenza Virus on the Seward Peninsula, Alaska: An Ethnohistoric Reconstruction, International Journal of Circumpolar Health, 57 (Supplement 1): 247-251.

2009 Luck and the Art of Leaving No Stone Unturned: The Search for Bear Rock Monument, in Kenneth L. Pratt (ed.), Chasing the Dark: Perspectives on Place, History and Alaska Native Land Claims. Volume 1, Shadowlands, Anchorage, BIA ANCSA Office: 230-240.

HOUSTON, Alasdair I., John M. McNAMARA, Zoltan BARTA and Kirk C. KLASING

2007 The Effect of Energy Reserves and Food Availability on Optimal Immune Defense, Proceedings of the Royal Society B-Biological Sciences, 274(1627): 2835-2842.

\section{KOUTSKY, Kathryn}

1981a Early Days on Norton Sound and Bering Strait: An Overview of Historic Sites in the BSNC Region. Volume III - The Port Clarence and Kauwerak Areas, Fairbanks, University of Alaska Fairbanks, Cooperative Park Studies Unit, Anthropology and Historic Preservation, Occasional Paper, 29.

1981b Early Days on Norton Sound and Bering Strait: An Overview of Historic Sites in the BSNC Region. Volume II - The Wales Area, Fairbanks, University of Alaska Fairbanks, Cooperative Park Studies Unit, Anthropology and Historic Preservation, Occasional Paper, 29.

1981c Early Days on Norton Sound and Bering Strait: An Overview of Historic Sites in the BSNC Region. Volume I - The Shishmaref Area, Fairbanks, University of Alaska Fairbanks, Cooperative Park Studies Unit, Anthropology and Historic Preservation, Occasional Paper, 29.

1982 Early Days on Norton Sound and Bering Strait: An Overview of Historic Sites in the BSNC Region. Volume VIII - The St. Michael and Stebbins Area, Fairbanks, University of Alaska Fairbanks, Cooperative Park Studies Unit, Anthropology and Historic Preservation, Occasional Paper, 29. 


\section{NOME DAILY NUGGET}

1918 Newspaper report on December 23, Nome, Nome Publishing Company, RAS-1009-11 ALASKA PER MFILM (January 2, 1915 - December 30, 1918), Elmer E. Rasmuson Library, University of Alaska Fairbanks.

OQUILLUK, William A.

1973 People of Kawerak: Legends of the Northern Eskimo, Anchorage, Alaska Pacific University Press.

PERSON, Brian T., Alex K. PRICHARD, Geoffry M. CARROLL, David A. YOKEL, Robert S. SUYDAM and John C. GEORGE

2007 Distribution and Movements of the Teshekpuk Caribou Herd 1990-2005: Prior to Oil and Gas Development, Arctic, 60(3): 238-250.

POST, Eric, Pernille S. BOVING, Christian PEDERSEN and Megan A. MacARTHUR 2003 Synchrony between Caribou Calving and Plant Phrenology in Depredated and Non-Depredated Populations, Canadian Journal of Zoology, 81(10): 1709-1714.

PRATT, Kenneth L.

1984 Yukon-Kuskokwim Eskimos, Western Alaska: Inconsistencies in Group Identification, M.A. thesis, Western Washington University, Bellingham.

2001 The Ethnohistory of Caribou Hunting and Interior Land Use on Nunivak Island, Alaska Journal of Anthropology, 1(1): 28-55.

2004 Observations on Researching and Managing Alaska Native Oral History: A Case Study, Alaska Journal of Anthropology, 2(1-2): 138-153.

2009a A History of the ANCSA 14(h)(1) Program and Significant Reckoning Points, 1975-2008, in Kenneth L. Pratt (ed.), Chasing the Dark: Perspectives on Place, History and Alaska Native Land Claims. Volume 1, Shadowlands, Anchorage, BIA ANCSA Office: 3-41.

2009b Nuniwarmiut Land Use, Settlement History and Socio-Territorial Organization, 1880-1960, Ph.D. dissertation, University of Alaska Fairbanks, Fairbanks.

2012 Reconstructing 19th-Century Eskimo-Athabascan Boundaries in the Unalakleet River Drainage, Arctic Anthropology, 49(2): 94-112.

RAY, Dorothy J.

1964 Nineteenth Century Settlement and Subsistence Patterns in Bering Strait, Arctic Anthropology, 2(2): 61-94. 
1975 The Eskimos of the Bering Strait, 1650-1898, Seattle, University of Washington Press.

RAY, Dorothy J. (ed.)

1966 The Eskimo of St. Michael and Vicinity as Related by H.M.W. Edmonds, Anthropological Papers of the University of Alaska, 13(2).

RENNER, Louis L.

1979 Pioneer Missionary to the Bering Sea Eskimos: Bellarmine Lafortune, SJ, Portland, Binford and Mort.

SHEPPARD, William L.

1983 Continuity and Change in Norton Sound: Historic Sites and Their Contexts, Fairbanks, University of Alaska Fairbanks, Cooperative Park Studies Unit, Anthropology and Historic Preservation, Occasional Paper, 37.

1986 Variability in Historic Norton Bay Subsistence and Settlement, Ph.D. dissertation, Northwestern University, Evanston.

STERN, Richard O. and Erin RYDER

2009 Archaeological Monitoring of AVEC Bulk Fuel Upgrade and Fuel Delivery Lines Trenching at Brevig Mission, Seward Peninsula Alaska, report prepared for CE 2 Engineers, Inc. (Anchorage) by Northern Land Use Research, Inc. (Fairbanks), draft version on file, Anchorage, BIA ANCSA Office.

WOLFE, Robert J.

1982 Alaska's Great Sickness, 1900: An Epidemic of Measles and Influenza in a Virgin Soil Population, Proceedings of the American Philosophical Society, 126(2): 91-121.

ZAGOSKIN, Lavrentiy A.

1967 Lieutenant Zagoskin's Travels in Russian America, 1842-1844: The First Ethnographic and Geographic Investigations in the Yukon and Kuskokwim Valleys in Alaska, translated by Penelope Rainey, Henry N. Michael (ed.), Toronto, Arctic Institute of North America, University of Toronto Press. 